\title{
PENGGUNAAN ALAT PERAGA FISIKA BERBASIS LINGKUNGAN PADA PEMBELAJARAN KONSTEKTUALUNTUK MENINGKATKAN MINAT DAN KETERAMPILAN CALON GURU
}

\author{
Safriana, Nuraini Fatmi, Syarifah Rita Zahara \\ Program Studi Pendidikan Fisika FKIP Universitas Malikussaleh \\ Penulis Korespondensi: safriana@unimal.ac.id
}

\begin{abstract}
Abstrak : Pelatihan ini bertujuan untuk meningkatkan minat dan keterampilan calon guru $\backslash$ di program studi pendidikan fisika FKIP universitas Malikussaleh dalam menggunakan alat peraga fisika berbasis lingkungan pada pembelajaran kontekstual. Selain itu, Pelatihan ini juga diharapkan dapat meningkatkan kerja sama akademik antara sekolah dan universitas dan pemanfaatan lingkungan sebagai media dalam pembuatan alat peraga. Metode yang digunakan dalam pelatihan ini terdiri dari (1) metode Ceramah/Penyuluhan, dimaksudkan untuk menyampaikan informasi untuk materi yang bersifat umum dan teoritis, dalam hal ini adalah materi pembuatan alat peraga berbasis lingkungan dengan penerapan pembelajaran kontekstual (Contextual Teaching and Learning), (2) metode Dialogis, dimaksudkan untuk Tanya jawab dan diskusi tentang bagaimana pembuatan alat peraga. (3) Metode Pelatihan, dimaksudkan mampu menekan tingkat kebosanan siswa saat mempelajari konsep fisika sehingga dapat meningkatkan minat belajar siswa, dan memberikan gambaran kepada calon guru bahwa proses belajar-mengajar dengan menggunakan alat peraga sangat efektif untuk dilakukan. Kegiatan pelatihan untuk calon-calon guru dalam pembuatan alat peraga banyak memberikan manfaat, karena calon- calon guru bisa merancang dan mempraktekkan langsung di depan siswanya sehingga menghasilkan pembelajaran yang efektif.
\end{abstract}

Kata Kunci : Alat Peraga, Kontekstual, Minat, Keterampilan Calon guru

\section{USE OF ENVIRONMENT-BASED PHYSICAL ASSEMBLY TOOLS IN CONSTECTUAL LEARNING FOR IMPROVING TEACHERS 'INTERESTS AND \\ SKILLS}

\begin{abstract}
This training aims to improve the interests and skills of prospective teachers in the FKIP physics education study program at Malikussaleh University in using environmentalbased physics teaching aids in contextual learning. In addition, this training is also expected to improve academic cooperation between schools and universities and the use of the environment as a medium in making teaching aids. The method used in this training consists of (1) lecture / counseling method, intended to convey information for general and theoretical material, in this case the material for making teaching aids based on the environment with the application of contextual learning (Contextual Teaching and Learning), (2) Dialogical methods, intended for questioning and discussion about how to make teaching aids. (3) Training Methods, intended to be able to reduce the level of student boredom when learning physics concepts so as to increase students' interest in learning, and provide an overview to pre service teachers that the teaching-learning process using teaching aids is very effective to do. Training activities for pre service teachers in the manufacture of teaching aids provide
\end{abstract}


many benefits, because pre service teachers can design and practice directly in front of their students so as to produce effective learning.

Keywords: Teaching Aids, Contextual, Interests, Pre Service Teacher Skills

\section{PENDAHULUAN}

Tujuan pendidikan nasional yang dirumuskan dalam undang-undang nomor 20 tahun 2003 adalah untuk berkembangnya potensi siswa agar menjadi manusia yang beriman bertakwa kepada tuhan yang maha esa, berakhlak mulia, sehat, berilmu, cakap, kreatif, mandiri dan menjadi warga negara yang demokratis serta bertangung jawab. Kurikulum 2013 dirancang dengan tujuan untuk mempersiapkan insan indonesia supaya memiliki kemampuan hidup sebagai pribadi dan warga negara yang beriman, produktif, kreatif, inovatif,dan efektif serta mampu berkonstribusi pada kehidupan bermasyarakat, berbangsa, bernegara dan peradaban dunia.(Kemendiknas, 2011).

Pada hakikatnyapendidikan adalah suatu usaha penyiapan subjek didik untuk menghadapilingkungan hidupyang selalumengalami perubahanyang semakinpesat. Pendidikanjuga merupakankiat dalam menerapkan prinsip-prinsip ilmu pengetahuan dan teknologibagi pembentukan manusiaseutuhnya. Pendidikan harus mampu menghasil kanlulusanyang mampuberpikir global (thinkglobally), dan mampu bertindak local (act locally), serta dilandasiolehahklakyang mulia (Bhawayasa, 2011).

Kenyataan dilapanganmenunjukkan kualitas mutu pendidikan diIndonesia saatinisangatmemprihatinkan, hal ini di tandai dari hasil observasi awal yang dilakukan penulis di beberapa sekolah tingkat SMA disekitar kabupaten bireun, banyak guru yang mengajar masih dengan cara lama, yakni tidak ada inovasi dalam pembelajaran. Hasilbelajar sainskhususnyamata pelajaranfisika masihbelum menggembirakan. Guru hanyamenggunakan sebuah buku sebagaisatu- satunyabahanajar, dalam hal ini guru di nilai kurang kreatif dalam mengelola pembelajaran. Padahal materi fisika merupakan materi yang sangat berkaitan dengan alam, jadi begitu mudah jika disajikan dalam pembelajaran konstektual. Semua permasalahan di fisika dapat diuraikan dan diselesaikan dengan cara konstektual, penyajian materi fisika dapat dipermudah dengan cara menyajikan materi berbantuan alat peraga yang terdapat di alam,

Faktorlainyang diduga sebagai penyebab rendahnya hasil belajar sains khususnya mata pelajaran fisika di SMA adalah pembelajaran fisika yang dijalankan oleh guru selama ini masih memisahkan pengetahuan formal fisika siswa dengan pengalaman sehari-hari siswa, sehingga siswa berasumsi bahwa pelajaran fisika tidak mempunyai hubungan dengan kehidupan mereka. Hal ini lah yang membuat siswa beranggapan bahwa pelajaran fisika merupakan pelajaran yang tersukar karena bersifatabstrakdan rumit. Pemikiran ini bisa di ubah dengan cara menyajikan materi fisika secara konstextual dan berbantuan alat peraga yang tersedia di alam.

Menurut B. Hartati (2010) menyatakan bahwa "kegiatan praktikum yang menggunakan alat peraga dapat meningkatkan keterampilan berpikir kritis siswa, sebelum menggunakan alat peraga, 68,8\% peserta didik memiliki kemampuan berpikir kritis cukup, sebanyak 19,8\% dalam katagori tinggi. Berbeda situasinya setelah mengikuti praktikum dengan menggunakan alat peraga, keterampilan berpikir peserta didik naik menjadi $60,4 \%$ ada dalam katagori tinggi, dan katagori rendah sebesar 27,1 \%". Menurut Sang Putu jaya(dalam jurnalnya menjelaskan bahwa "Modulfisika kontekstual ini sangat baik dan layak untuk digunakan dalam pembelajaran". MenurutNurhadiyang dikutipolehSugiyanto 
(2007)"Pembelajaran kontekstual adalah konsep yang mendorong guru untuk menghubungkan antara materi yang diajarkandan situasi dunia nyat asiswa." Pengetahuan dan keterampilan siswa diperoleh dari usaha siswa mengkonstruksi sendiri pengetahuan dan keterampilan baru ketika siswa belajar. Pembelajaran kontekstual menerapkan tujuh komponen utama yakni konstruktivisme, bertanya, menemukan, masyarakat belajar, pemodelan, refleksi, dan penilaian sebenarnya.

Walaupun fisika hanya pendamping untuk kompetensi program keahlian, tetapi harus dapat menjadi dasar yang kuat guna mendukung kompetensi program keahliannya. Maka perlu adanya peningkatan kualitas pembelajaran dengan mengadakan pelatihan penggunaan alat peraga melalui pembelajaran konstektual. Kegiatan ini bertujuan untuk membuka wawasan guru dalam memanfaatkan lingkungan dalam merancang alat peraga serta menggunakan pendekatan konstektual dalam menjelaskan materi ajar, dengan demikian proses belajar mengajar pada materi fisika bisa disajikan dengan tampilan mudah dipahami dan yang menarik.

\section{METODE}

Kegiatan pengabdian kepada calon guru dilaksanakan pada bulanAgustus 2018. Kegiatani ni diawali dengan langkah awal yaitu kegiatan pembuatan alat peraga fisika di Universitas Malikussaleh (FKIP FISIKA). Selanjutnya Dosen memberikan arahan kepada calon guru tentang model-model pembelajaran yang sesuai yang biasa diterapkan dengan menggunakan alat peraga pada tanggal 20 Agusts 2018, dan kegiatan praktek pembuatan alat peraga dan pelatihan dilaksanakan pada tanggal 30 Juli 2018 sampai 9 Oktober 2018.

Materi yang dibahas dalam kegiatan pengabdian kepada masyarakat ini meliputi:

a. meningkatkan motivasi calon guru dalam pembuatan alat peraga

b. meningkatkan minat belajar siswa

c. teknis pembuatan alat peraga

d. Penerapan pembelajaran kontekstual (Contextual Teaching and Learning).

Untuk mencapai tujuan kegiatan pengabdian kepada masyarakat ini dengan Menggunakan metode sebagai berikut.

a. Metode Ceramah/Penyuluhan, dimaksudkan untuk menyampaikan informasi untuk materi yang bersifat umum dan teoritis, dalam hal ini adalah materi pembuatan alat peraga berbasis lingkungan dengan penerapan pembelajaran kontekstual (Contextual Teaching and Learning).

b. Metode Dialogis, dimaksudkan untuk Tanya jawab dan diskusi tentang bagaimana pembuatan alat peraga.

c. Metode Pelatihan, dimaksudkan mampu menekan tingkat kebosanan siswa saat mempelajari konsep fisika sehingga dapat meningkatkan minat belajar siswa, dan memberikan gambaran kepada calon guru bahwa proses belajar-mengajar dengan menggunakan alat peraga sangat efektif untuk dilakukan.

\section{HASIL DAN PEMBAHASAN}

Kegiatan pelatihan ini dilaksanakan untuk calon-calon guru di lingkungan Universitas Malikussaleh (Fakultas Keguruan dan Ilmu Pendidikan), yang berupa pembuatan alat peraga berbasis lingkungan dengan pembelajaran CTL. Kegiatan dilaksanakan pada 30 Juli 2018 sampai 9 Oktober 2018 yang diisi dengan kegiatan mempraktekkan alat peraga yang dibuat 
oleh calon guru, yang dimaksudkan untuk menyampaikan informasi tentang materi yang bersifat umum dan teoritis, dalam hal ini adalah materi Fisika tentang energy kinetic dan energy potensial; kegiatan dialogis, dimaksudkan untuk Tanyajawab dan diskusi tentang bagaimana calon guru membuat alat peraga. Kegiatan pelatihan, dimaksudkan untuk menanamkan kecakapan,ketrampilan teknis dan praktis dalam pembuatan alat peraga disekolah, dan memberikan gambaran yang konkrit di lapangan tentang pembuatan alat peraga.

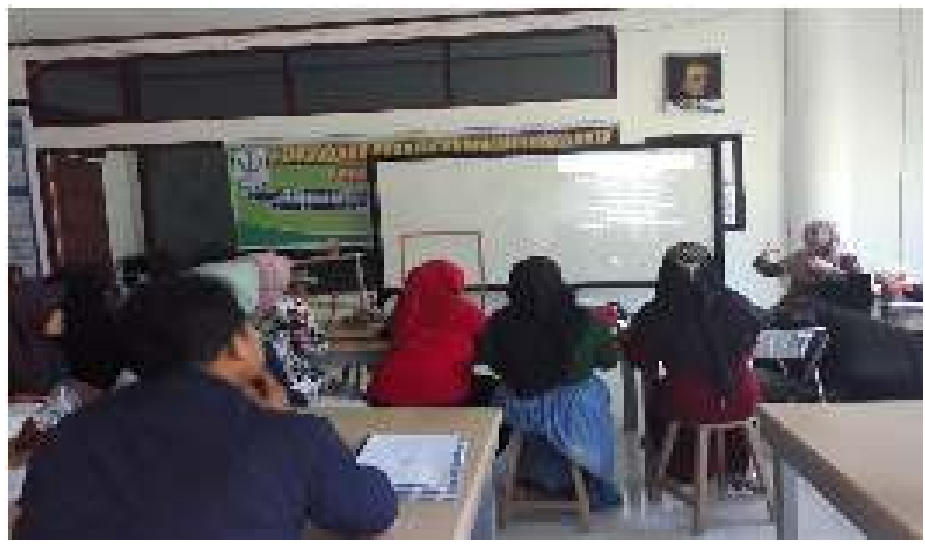

Gambar. 1 Pelaksanaan Workshop

Kegiatan program pengabdian kepada masyarakat yang telah dilaksanakan ini berjalan dengan lancar sesuai dengan tujuan yang diharapkan dari kegiatan ini, dan mendapatkan hasil yang baik. Para calon guru mendapat sharing pengetahuan tentang bagaimana praktek pembuatan alat peraga apabila dikaitkan dengan konsep fisika di sekolah. Para mahasiswa mendapat tambahan pengetahuan tentang bagaimana cara menggunakan alat peraga dengan baik. Kegiatan ini selain mendapat respon positif dari dosen-dosen di lingkungan Universitas Malikussaleh, juga mendapat dukungan penuhdari Dekan FKIP sejak dari tahapan pembuatan alat peraga sampai pada mempraktekkan alat peraga ini. Diharapkan dengan adanya kegiatan pembuatan alat peraga berbasis lingkungan dengan pembelajaran CTL dan meningkatkan minat belajar siswa, karena pembelajaran dengan pendekatan CTL merupakan pembelajaran yang efektif. Dan semoga dapat diterapkan disekolah-sekolah setiap belajar fisika.

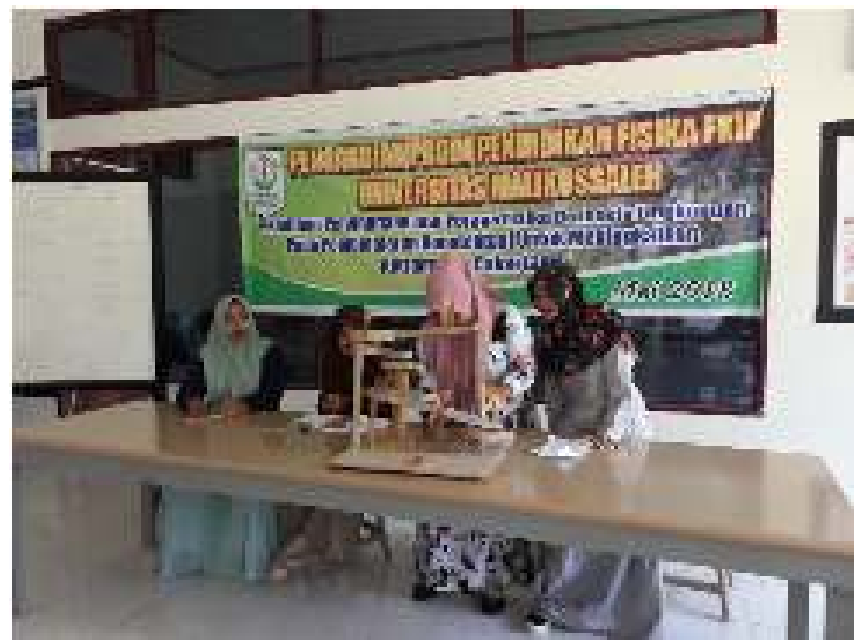

Gambar 2. Mahasiswa Mempresentasikan Alat Peraga yang Telah Dibuat 


\section{PENUTUP}

Berdasarkan hasil pelaksanaan pengabdian kepada masyarakat yang berupa pelatihan Penggunaan Alat Peraga Fisika Berbasis Lingkungan Pada Pembelajaran Konstektual yang telah dilaksanakan, dapat disimpulkan sebagai berikut:

a. kegiatan pengabdian kepada masyarakat untuk calon-calon guru dalam pembuatan alat peraga banyak memberikan manfaat, karena calon- calon guru bisa mempraktekkan langsung didepan siswanya. Alat peraga adalah suatu media yang dapat digunakan untuk merangsang pikiran, perasaan, perhatian dan kemauan siswa sehingga dapat mendorong terjadinya proses belajar pada diri siswa. Selain itu, Alat peraga juga merupakan salah satu alat yang dapat digunakan untuk membangkitkan minat siswa untuk belajar.

b. kegiatan pengabdian kepada masyarakat dalam hal pembuatan alat peraga dapat dijadikan sebagai sarana komunikasi untuk menyampaikan konsep yang diberikan oleh guru, sehingga pada setiap belajar fisika diharapkan bisa menggunakan alat peraga dengan baik untuk menghasilkan pembelajaran yang efektif.

\section{DAFTAR PUSTAKA}

A. Kmg. Suartini, Md. Sumantri, I. K. S. (2014). Penaruh Model Pembelajaran Kontekstual Berbantuan Alat Peraga Kartu Huruf Terhadap Keterampilan Membaca Permulaan Siswa Kelas I SD. Mimbar PGSD Universitas Pendidikan Ganesha, 2(1).

Darwan, \& Sri Maria Ulfa, M. (2012). Perbedaan Minat Belajar Siswa Antara Yang Menggunakan Alat Peraga Dengan Yang Tidak Menggunakan Minat Belajar Pada Mata Pelajaran Matematika. Eduma.

Hasnawati. (2006). Pendekatan Contextual Teaching and Learning. Jurnal Ekonomi Dan Pendidikan.

Hutagaol, K. (2013). Pembelajaran Kontekstual untuk Meningkatkan Kemampuan Representasi Matematis Siswa Sekolah Menengah Pertama. Jurnal Ilmiah Program Studi Matematika STKIP Siliwangi Bandung, 2(1).

Juwairiyah, J. (2013). Alat Peraga dan Media Pembelajaran Kimia. Visipena, 4(1), 1-13. Retrieved from http://ejournal.stkipgetsempena.ac.id/index.php/visipena/article/view/49. diakses pada tanggal 3 April 2018.

Resmiyati, E. (2016). Penggunaan Aalat Peraga Untuk Meningkatkan Aktivitas Dan Hasil Belajar Siswa Pada Pelajaran Matematika Kelas IV SD Negeri 9 Metro.

Ricky Darmawa. (2015). Pengaruh Minat Belajar Dan Perhatian Orang Tua Terhadap Prestasi Belajar Siswa. Jakarta:

Sudjana, N., \& Rivai, A. (2007). Media Pengajaran. Sinar Baru Algensindo (Vol. 8). https://doi.org/10.5194/hess-11-1609-2007. diakses pada tanggal 3 April 2018. 